Tohoku J. exp. Med., 1986, 149, 151-161

\title{
Antibodies Specific for Methylated DNA \\ Elicited in Rabbits Recognize only a Single Strand Region of DNA Containing 7-Methylguanine
}

\author{
Yoshiniko Kawarada and Eiji Okuhara \\ Department of Biochemistry, Akita University School of \\ Medicine, Akita 010
}

\begin{abstract}
Kawarada, Y. and Onuhara, E. Antibodies Specific for Methylated DNA Elicited in Rabbits Recognize only a Single Strand Region of DNA Containing 7-Methylguanine. Tohoku J. exp. Med., 1986, 149 (2), 151-161— Immunogenicity of methylated DNA (Me-DNA) was investigated in connection with the changes of the high order structure. Antibodies specific for Me-DNA were elicited in the rabbits with DNA methylated at different extents. When Me-DNA was chromatographed on a hydroxyapatite column and was separated into single and double stranded forms, Me-DNA eluted at single strand position was found to react only with the anti-Me-DNA antibodies. In order to examine the immunogenicity of both single and double stranded forms, each form was injected in rabbits respectively. No specific antibodies were produced for the double stranded form, whereas the single stranded form showed a potent immunogenicity. On the other hand, the antigenicity of the single stranded Me-DNA was decreased or lost in parallel with the extent of the release of 7-methylguanine residues from the molecule on heating under the neutral condition. These results revealed that single stranded structure of Me-DNA is immunogenic or antigenic and that 7methylguanine residues of Me-DNA play an important role in forming a characteristic structure required for the manifestation of its specific antigenicity. methylated DNA ; anti-methylated DNA antibody ; antigenic feature of methylated DNA ; hydroxyapatite column chromatography of methylated DNA
\end{abstract}

Although native DNA is not immunogenic in normal animals (Stollar 1973), heat denatured DNA (Plescia 1964; Forsen et al. 1970), poly d (A-T) (Beverly and Erlanger 1978), left-handed Z-DNA (Lafer et al. 1981), synthetic double and triple stranded RNAs (Schwartz and Stollar 1969; Guigues and Leng 1976 ; Kitagawa and Okuhara 1980), RNA-DNA hybrid (Stollar 1970), and viral double stranded RNA (Kitagawa et al. 1977) are immunogenic. Antibodies to helical nucleic acids can serve as valuable reagents for the study of these structures in

Received December 18, 1985 ; accepted for publication April 16, 1986.

Abbreviations: Me-DNA, methylated DNA; MBSA, methylated bovine serum albumin; Tm, melting temperature; SSC, standard saline citrate; DMS, dimethyl sulfate; DMSO, dimethyl sulfoxide 
biological systems. In a previous paper, Igarashi and Okuhara (1976) demonstrated the production of antibodies specific for methylated salmon sperm DNA in rabbits aiming at utilization of antibodies to chemically modified DNA in studies of structure-function relationship of DNA. The detail of the antigenic specificity manifested by methylated DNA was not elucidated at that time but the experiments indicated that methylated guanine residues on DNA molecules might play a major role in the antigenic determination. In addition, it remained questionable that heat-denatured Me-DNA did not exhibit any antigenicity.

We planned in this connection to examine more detailed antigenic features of the Me-DNA by pursuing the correlation between the antigenic activity and chromatographic behavior of the Me-DNA on a hydroxyapatite column. Moreover, some possible role of 7-methylguanine residues of Me-DNA in manifestation of antigenicity was investigated. In this paper, we report that the single stranded structure and 7-methylguanine residues of the Me-DNA are essential for the formation of immunogenic structure.

\section{Materials and Methods}

Chemicals. Sodium dodecyl sulfate obtained from Tokyo Chemical Industries Co. Ltd. (Tokyo) was recrystallized from ethanol solution. Phenol was redistilled under reduced pressure. The DNA was prepared from salmon sperm (Oncorhynchus Keta) by the usual method in our laboratory (Okuhara 1970) and further purified according to the procedure of Marmur (1961). Dimethyl sulfate (DMS) was purchased from Nakarai Chemicals, Ltd. (Kyoto). Methylated bovine serum albumin (MBSA) was prepared from crystalline bovine serum albumin fraction V (Miles Laboratories, Elkhart, Ind., USA) by the method of Mandell and Hershey (1960). Complete Freund's adjuvant was purchased from Iatron Laboratories (Tokyo,). Hydroxyapatite (hypatite C) was obtained from Clarkson Chemical Company Inc. (Williamsport, Pa., USA) and dimethyl sulfoxide (DMSO) from Wako Pure Chemical Industries Ltd. (Osaka). All other chemicals used were of analytical grade.

Animals. Female japanese white rabbits weighing $3-4 \mathrm{~kg}$ were used.

Methylation of DNA. Methylation of salmon sperm DNA was carried out according to the method of Pochon and Michelson (1967) with a slight modification. T'o $4 \mathrm{ml}$ of DNA solution $(1 \mathrm{mg} / \mathrm{ml}$ in $0.375 \mathrm{M} \mathrm{NaCl})$ was added $1 \mathrm{ml}$ of $2 \mathrm{M}$ sodium cacodylate buffer $(\mathrm{pH}$ 6.0 ) and then $0.1 \mathrm{ml}$ of DMS was added to this solution. The reaction mixture was stirred for several hours at $4^{\circ} \mathrm{C}$, and then dialysed overnight against standard saline citrate (SSC) to remove excess DMS at $4^{\circ} \mathrm{C}$, and finally added 2 volumes of cold ethanol. The resulting methylated DNA was spooled up on a glass rod. After washing with 70\%, 95\% and finally $99 \%$ ethanol, it was dried and stocked at $-20^{\circ} \mathrm{C}$ until use.

Base analysis. A specimen of Me-DNA (ca. $1 \mathrm{mg}$ ) was hydrolyzed in a sealed tube with $1 \mathrm{ml}$ of $88 \%$ formic acid at $175^{\circ} \mathrm{C}$ for $30 \mathrm{~min}$ and then evaporated to dryness in vacuo. The residues were dissolved in $1 \mathrm{ml}$ of $0.1 \mathrm{~N} \mathrm{HCl}$ and applied to a column $(0.9 \times 50 \mathrm{~cm}$, i.d.) packed with Hitachi Custom Ion-Exchange Resin \#2612 (cation-exchange type). The column was eluted with $0.3 \mathrm{M}$ potassium phosphate buffer $(\mathrm{pH} 5.4)$ at $60^{\circ} \mathrm{C}$. The flow rate was $90 \mathrm{ml}$ per hour. The effluent was monitored at $260 \mathrm{~nm}$ using a Hitachi Model 034 multiwavelength flow monitor. Under these conditions, bases were eluted in order of thymine, guanine, 7-methylguanine, adenine and cytosine.

Melting profile of Me-DNA. During denaturation of Me-DNA (ca. $50 \mu \mathrm{g} / \mathrm{ml}$ in SSC), the absorbance was measured at $260 \mathrm{~nm}$ with a Hitachi Model 139 spectrophotometer equipped with a Komatsu SPS-H 139 thermostatic cell block. The temperature was raised 
from $20^{\circ} \mathrm{C}$ to $95^{\circ} \mathrm{C}$ at a constant rate of $1^{\circ} \mathrm{C} /$ min by using a Komatsu Medel SPR DC power controller equipped with a Komatsu Model KPC-2 automatic temperature programmer. The accurate temperature was measured by a thermocouple inserted in a cuvette. The absorbance and temperature were recorded on the same chart of a Hitachi Model 056 two pen recorder.

Immunization. Immunization was carried out as follows: One mg of Me-DNA in 0.9 $\mathrm{ml}$ of SSC and an equal weight of MBSA in $0.1 \mathrm{ml}$ of water were mixed. The complex emulsified with an equal volume of complete Freund's adjuvant was injected intramuscularly into rabbits at one week intervals and blood was drawn one week after the last injection. The complement present in the sera was inactivated by incubation at $56^{\circ} \mathrm{C}$ for $30 \mathrm{~min}$ and then cold hemagglutinins were removed by absorption on sheep erythrocytes at low temperature. The sera thus prepared were lyophilized and kept at $-20^{\circ} \mathrm{C}$. The quantitative complement fixation measurement was made by a modification of Kolmer's micromethod as previously described (Matsumoto and Okuhara 1974).

Hydroxyapatite column chromatography. Hydroxyapatite column chromatography of Me-DNA was performed according to the method of Bernardi (1971). One mg of Me-DNA in $0.01 \mathrm{M}$ potassium phosphate buffer ( $\mathrm{pH}$ 6.8) was applied to a hydroxyapatite column $(1.7 \times 5 \mathrm{~cm}$, i.d.) equilibrated with the same buffer and eluted with a linear gradient of potassium phosphate buffer ( $\mathrm{pH} 6.8$ ) from $0.01 \mathrm{M}$ to $0.5 \mathrm{M}$ in a total volume of $200 \mathrm{ml}$. The flow rate was $40 \mathrm{ml}$ per hour and $4 \mathrm{ml}$ fractions were collected. To estimate the antigenic activity, $0.1 \mathrm{ml}$ of each fraction was used for the quantitative complement fixation measurement.

Denaturation of Me-DNA with DMSO. A solution of Me-DNA $(1 \mathrm{mg} / \mathrm{ml}$ in $0.01 \mathrm{M}$ $\mathrm{NaCl}$ ) was incubated with ten volumes of DMSO at $37^{\circ} \mathrm{C}$ for $30 \mathrm{~min}$. The incubation mixture was dialyzed against $0.01 \mathrm{M}$ potassium phosphate buffer $(\mathrm{pH} 6.8)$ at $4^{\circ} \mathrm{C}$ overnight and then applied to the hydroxyapatite column.

\section{RESULTS}

\section{Properties of methylated DNA}

Fig. 1 shows the relationship between the methylation rate of guanine residues at $\mathrm{N}^{7}$ and reaction time. Under the conditions described in Materials and Methods, methylation reaction of guanine residues of DNA proceeded efficiently.

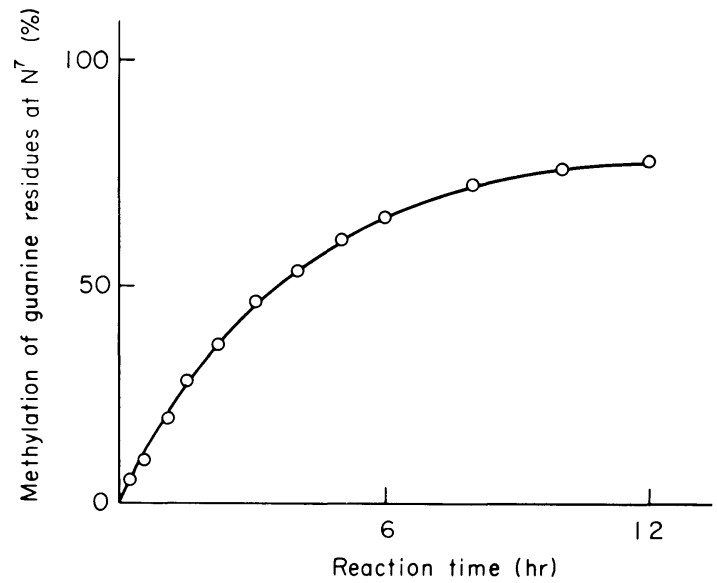

Fig. 1. Time course of methylation of DNA with dimethyl sulfate. The methylation procedure was described in the text. 


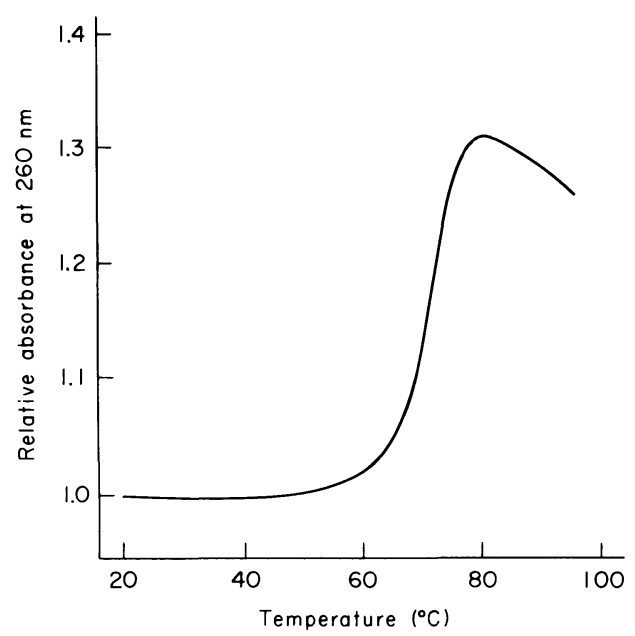

Fig. 2. Thermal denaturation profile of $70 \%$ methylated DNA. The measuring method was described in the text.

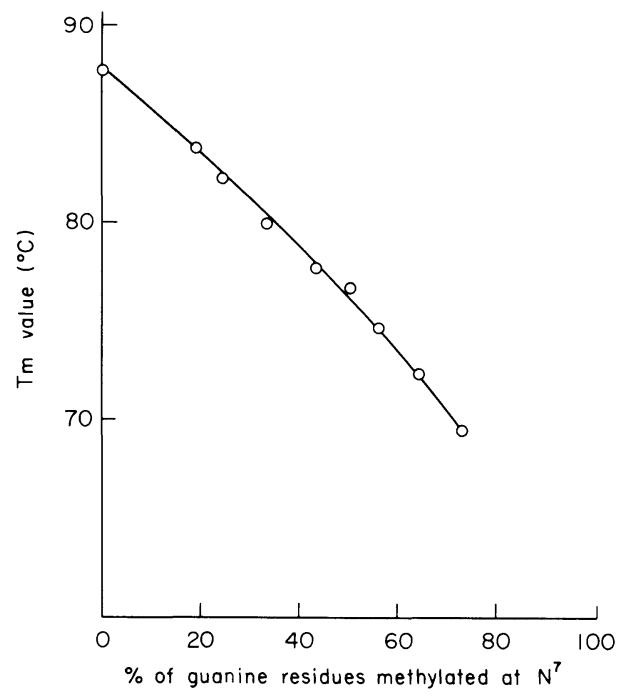

Fig. 3. Correlation between the extent of methylation of guanine residues of DNA at $\mathrm{N}^{7}$ and melting temperature. Measuring conditions were same as Fig. 2.

The maximum methylation rate was approximately $80 \%$. Any modified bases other than 7-methylguanine were not detected by the base analysis. DNA preparations methylated at different extents were made by altering the reaction time or the concentrations of dimethyl sulfate. Fig. 2 shows the melting profile of $70 \%$ methylated DNA. The Tm value was approximately $18^{\circ} \mathrm{C}$ lower than non-methylated DNA. At the temperature above $80^{\circ} \mathrm{C}$, the absorbance of Me-DNA was gradually decreased with time, and the decreasing rate was proportional to the extent of methylation of DNA (data not shown). Fig. 3 shows the correlation between the extent of methylation of DNA and Tm value. The Tm 
TABLE 1. Titers with sera during immunization

\begin{tabular}{|c|c|c|c|c|c|c|c|c|}
\hline \multirow{2}{*}{ Immunogens } & \multirow{2}{*}{$\begin{array}{c}\text { Rabbit } \\
\text { No. }\end{array}$} & \multicolumn{7}{|c|}{ Weeks after initial injection } \\
\hline & & 1 & 2 & 3 & 4 & 5 & 6 & 7 \\
\hline \multirow{3}{*}{$70 \%$ methylated DNA } & 145 & 0 & 8 & 29 & 22 & 21 & 24 & 23 \\
\hline & 146 & 0 & 40 & 170 & 170 & 110 & 110 & 110 \\
\hline & 147 & 0 & 13 & 76 & 150 & 140 & 130 & 160 \\
\hline \multirow{3}{*}{$40 \%$ methylated DNA } & 142 & 0 & 14 & 200 & 120 & 200 & 200 & 180 \\
\hline & 143 & 0 & 10 & 90 & 160 & 80 & 150 & 190 \\
\hline & 144 & 0 & 9 & 160 & 86 & 120 & 110 & 130 \\
\hline \multirow{2}{*}{$20 \%$ methylated DNA } & 151 & 0 & 0 & 15 & 160 & 170 & 220 & 180 \\
\hline & 152 & 0 & 0 & 25 & 50 & 110 & 340 & 140 \\
\hline \multirow{3}{*}{$7 \%$ methylated DNA } & 148 & 0 & 0 & 12 & 3 & 6 & 45 & 24 \\
\hline & 149 & 0 & 0 & 6 & 18 & 37 & 80 & 57 \\
\hline & 150 & 0 & 0 & 12 & 32 & 21 & 41 & 26 \\
\hline
\end{tabular}

Serum titer was determined as the reciprocal of the serum dilution required for $50 \%$ maximal complement fixation. The procedure for complement fixation was as follows : A mixture of $0.1 \mathrm{ml}$ of diluted antiserum, $0.1 \mathrm{ml}$ of homologous antigen $(1 \mu \mathrm{g})$ and 0 . $2 \mathrm{ml}$ of complement ( 2 units) was allowed to stand overnight at $4^{\circ} \mathrm{C}$ and then followed by incubation with $0.2 \mathrm{ml}$ of sheep erythrocytes sensitized with hemolysis ( 3 units) at $37^{\circ} \mathrm{C}$ for $30 \mathrm{~min}$. After centrifugation, optical density of the supernatant was measured at $541 \mathrm{~nm}$.

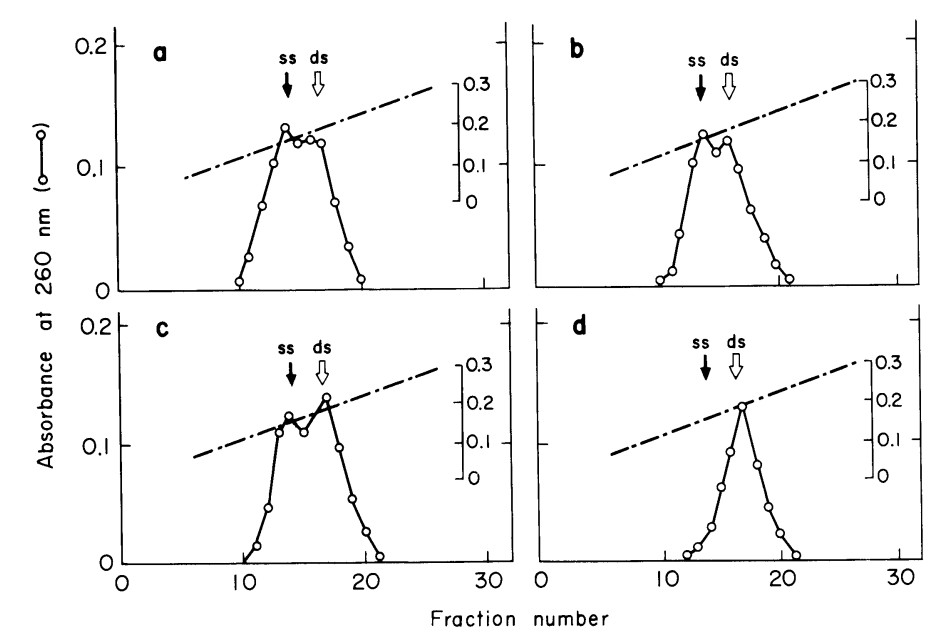

Fig. 4. Elution profile of Me-DNA on hydroxyapatite column. Methylation rate of guanine residues of DNA at $\mathrm{N}^{7}$ was : a) $70 \%$; b) $40 \%$; c) $20 \%$; d) $7 \%$. The chromatographic conditions were described in the text. $(\circ-\circ)$ indicates the absorbance at $260 \mathrm{~nm},(---)$, molar concentrations of phosphate in eluate $;\left(\begin{array}{c}\text { ss } \\ \downarrow\end{array}\right)$, elution position of heat denatured DNA (ss-DNA) and $\left(\begin{array}{l}\mathrm{ds} \\ \Omega\end{array}\right)$, elution position of native DNA (ds-DNA). 


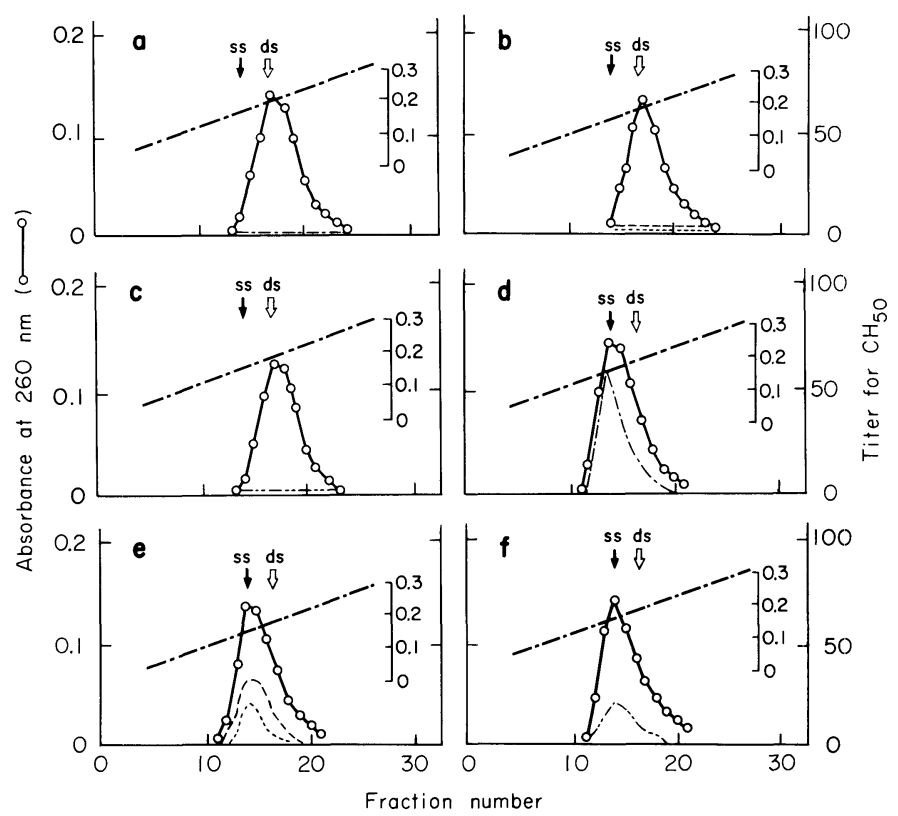

Fig. 5. Antigenic reactivity of Me-DNA eluted from hydroxyapatite column. Methylation rate of guanine residues of $\mathrm{DNA}$ at $\mathrm{N}^{7}$ was : a) and d) $70 \%$; b) and e) $30 \%$; c) and f) $7 \%$. In a), b), and c), the reaction mixture after methylation was directly applied to the hydroxyapatite column, while in d), e), and f), the methylated DNA was treated with DMSO and then applied to the column. Complement fixation reactions of four kinds of anti Me-DNA antisera $(1: 30)$ with $0.1 \mathrm{ml}$ of each fraction were carried out: $(-\bullet-)$ represents anti $70 \%$ methylated DNA antiserum ; (...) anti $40 \%$ methylated DNA antiserum; (•・・), anti 20\% methylated DNA antiserum; (- $\bullet$ -), anti $7 \%$ methylated DNA antiserum. The chromatographic conditions were described in the text. Other symbols are same as Fig. 4.

values were nearly linearly decreased with the increase of the methylation.

\section{Immunogenicity of DNA preparations methylated at different extents}

Four methylated DNAs were prepared at extents of 7\%,20\%,40\% and 70\%, respectively and the effect of methylation rate of Me-DNA on immunogenicity was examined. They were all found to be immunogenic. The antibody titer $\left(\mathrm{CH}_{50}\right)$ on weeks during immunization was shown in Table 1 . Twenty percent, $40 \%$ and $70 \%$ methylated DNA showed the similar antibody producing capacity, whereas $7 \%$ methylated DNA was hardly immunogenic. It means that the immunogenicity of Me-DNA largely depends on the methylation rate.

Correlation between chromatographic behavior of Me-DNA on hydroxyapatite column and antigenic reactivity of eluted peak fractions

Aiming at elucidating the antigenic structure of Me-DNA, Me-DNA was submitted to the hydroxyapatite column chromatography and it was separated 
into single and double stranded forms and the antigenic reactivities of each peak fraction were examined respectively. The elution patterns of four kinds of Me-DNAs are shown in Fig. 4. As seen in the figure, 70\%, 40\% and 20\% methylated DNAs were eluted as a broad peak which was formed by the overlap of two elution peaks corresponded to single and double stranded forms, whereas $7 \%$ methylated DNA was eluted as a single peak mainly in a double stranded form. Highly methylated DNA caused a partial denaturation resulting in a single stranded form. This partial denaturation of Me-DNA seemed to occur during a series of procedures for preparation such as precipitation with ethanol, dryness and redissolution. Therefore, to minimize the damage of Me-DNA, the reaction mixture after methylation was immediately applied to the hydroxyapatite column and the antigenic activity of the chromatographic peak fractions was examined. Seventy percent, $30 \%$ and $7 \%$ methylated DNAs were exclusively eluted as double stranded form as shown in Fig. 5 (a, b, c). The reactivities of each peak fraction with the corresponding antisera were completely negative in any case. The three Me-DNAs were treated with DMSO, and chromatographed in the same way. The majority of each Me-DNA was eluted in the single strand region as seen in Fig. 5 (d, e, f), and the eluates in the regions were found to be reactive with the corresponding antisera.

\section{Effect of heat treatment on antigenicity of $M e-D N A$}

In our previous work, we observed that $80 \%$ methylated DNA lost its antigenic reactivity by heating at $100^{\circ} \mathrm{C}$ for $10 \mathrm{~min}$ (Igarashi and Okuhara 1976). As regards the chemical properties of Me-DNA, Lawley and Brookes (1963) have reported that $\mathrm{N}$-glycosidic linkage of 7-methyldeoxyguanosine is easily hydrolized by heat treatment even at neutral conditions. Then we examined the effect of heat treatment on the antigenic reactivity of Me-DNA. Three Me-DNAs $(70 \%$, $30 \%$ and $7 \%$ ) were heated at $50{ }^{\circ} \mathrm{C}$ in SSC for several hours after denaturation with DMSO, respectively and then chromatographed on the hydroxyapatite column. The antigenic reactivities of the eluted peak fractions were measured by means of complement fixation test. As seen in Fig. 6, each of heat treated Me-DNAs was largely eluted in a form of single strand structure. The eluted peak fraction containing the single strand form did not show any reactivities with the corresponding antisera ( $\mathrm{a}, \mathrm{b}, \mathrm{c}$ in Fig. 6). In order to elucidate the mechanism that antigenic reactivities of Me-DNA were decreased or lost by heat treatment, the release of 7-methylguanine from Me-DNA on heating was examined quantitatively.

Correlation between the release of 7 -methylguanine from $M e-D N A$ and its antigenic reactivities

Seventy percent methylated DNA in SSC was incubated at $37^{\circ} \mathrm{C}$ for varied periods after treating with DMSO and then chromatographed on the hydroxy- 


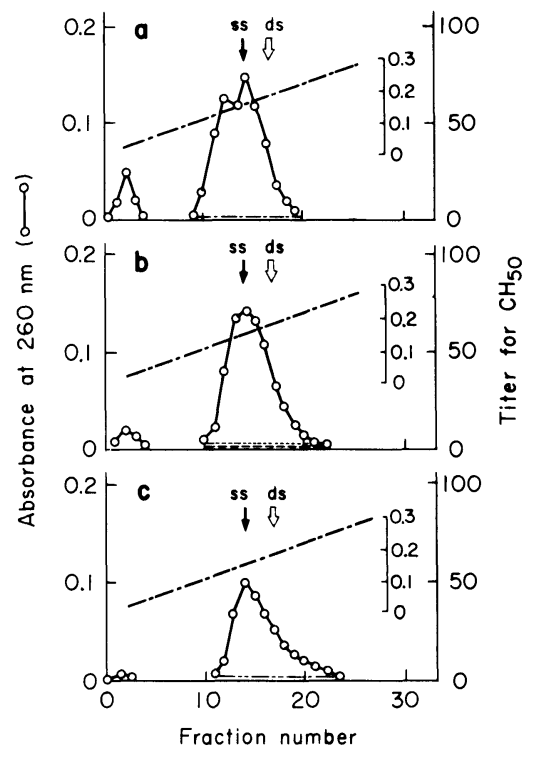

Fig. 6. Antigenic reactivity of heat treated MeDNA eluted from hydroxyapatite column. ( 0 - O) in panel a), b), and c) shows elution profiles of heated $70 \%, 30 \%$ and $7 \%$ methylated DNA, respectively. Excision rate of 7methylguanine from Me-DNA eluted in panel a), b) and c) was $70 \%, 90 \%$ and $70 \%$, respectively. The heat treatment and chromatographic conditions were described in the text. Complement fixation reactions of four kinds of anti Me-DNA antisera $(1: 30)$ with $0.1 \mathrm{ml}$ of each fraction were carried out: $(-\bullet-)$ represents anti $70 \%$ methylated DNA antiserum; (-..-), anti $40 \%$ methylated DNA antiserum ; ( $\cdots)$ ), anti $20 \%$ methylated DNA antiserum; $(-\cdots-)$, anti $7 \%$ methylated DNA antiserum. Other symbols are same as Fig. 4 .

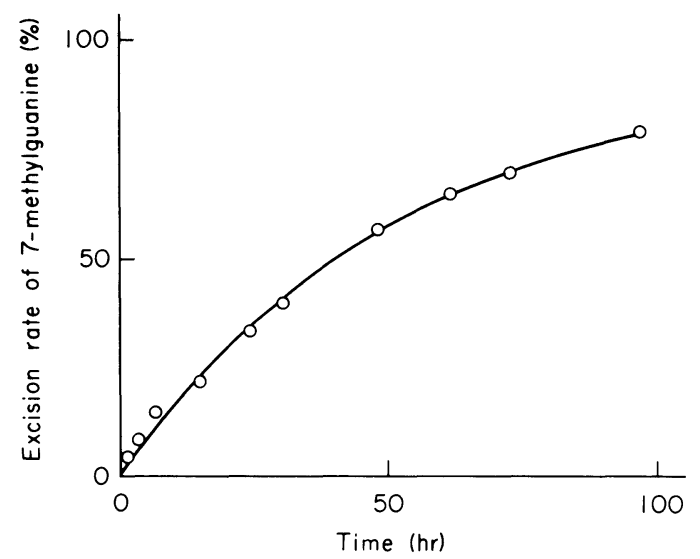

Fig. 7. Excision rate of 7-methylguanine from $70 \%$ methylated DNA by heat treatment.

apatite column. The excision rate of 7-methylguanine from Me-DNA was calculated from the base analysis of each specimen. Fig. 7 shows the time course of the excision rate of 7 -methylguanine residues. The half life of the release of 7 methylguanine from Me-DNA was approximately $40 \mathrm{hr}$. As shown in Fig. 8, the antigenic reactivities of Me-DNAs were decreased in parallel with the increasing release of 7 -methylguanine. In any case of Me-DNAs of which more than $20 \%$ of 7-methylguanine residues was lost, the antigenic reactivities of the resulting product dropped markedly.

\section{Discussion}

In the previous paper, we demonstrated that the antibodies against thermally untreated Me-DNA were elicited in rabbits and that thermally treated Me-DNA 
$\left(100^{\circ} \mathrm{C}, 10 \mathrm{~min}\right)$ did not react with the antiserum (Igarashi and Okuhara 1976). At that time, we thought that the Me-DNA used as immunogen had a double helical structure such as B-form. However it is literally well known that B-form DNA is non-immunogenic in animals (Stollar 1973). In order to confirm whether Me-DNA used as immunogen was double stranded form, we planned to fractionate Me-DNA preparations by using a hydroxyapatite column by which subtle differences in secondary and tertiary structures of nucleic acids could be discriminated (Bernardi 1971). As a result, two elution peaks appeared in the chromatogram and it was proved that one peak was in single strand DNA position and another one was in double strand DNA position (Fig. 4). Antigenic reactivities of each of peak fractions were examined. The melting profile and Tm values of the peak fractions for double stranded DNA revealed that it is preserved in a double helical form (Figs. 1 and 2). The antigenic reactivities were exclusively found in the elution position of single strand form (d, e, f in Fig. 5). Rabbits were immunized with the separated double stranded form on trial, but no antibodies were elicited. Accordingly, these results made clear that single structure of Me-DNA has antigenicity. So far as the transformation of double strand form of Me-DNA to single strand one is concerned, we inferred that it might be caused by a series of procedures after methylation such as spooling of the methylated product precipitated with ethanol, drying of the fiber and redissolving in solution for use as antigen. When the reaction mixture after methylation of native DNA was directly applied to the hydroxyapatite column, only one peak

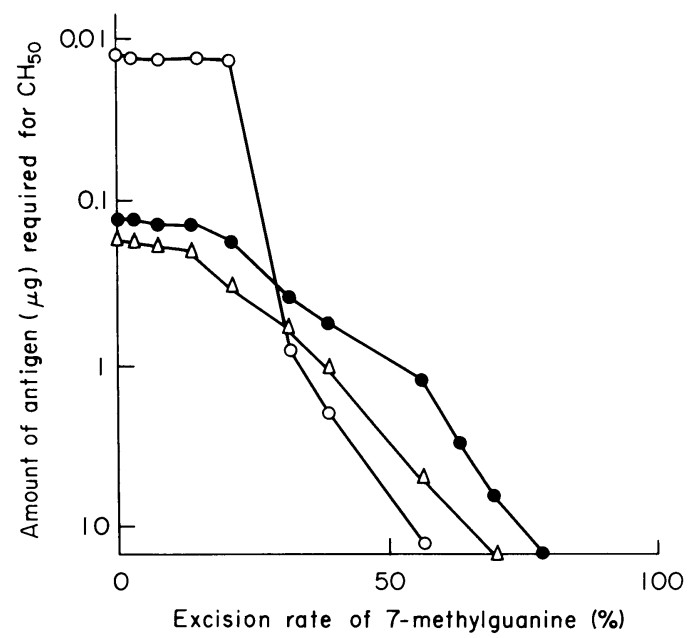

Fig. 8. Correlation between the release of 7 -methylguanine from $70 \%$ methylated DNA and antigenic reactivities. $(\bigcirc-0),(\bullet-\bullet)$, and $(\triangle-\triangle)$ represent complement fixation reactions of anti $70 \%$ methylated DNA, anti $20 \%$ methylated DNA, and anti 7\% methylated DNA antisera $(1: 30)$ with $0.1 \mathrm{ml}$ of $70 \%$ methylated DNA heated for varied periods after DMSO treatment. Antigenic reactivities of each antigen were represented as amount of antigen required for $\mathrm{CH}_{50}$. 
was eluted in the double stranded DNA position ( $a, b, c$ in Fig. 5). After all, it was recognized that the Me-DNA used as immunogen was a mixture of nonimmunogenic double strand form and immunogenic single one. As shown in Table 1, when a variety of Me-DNA preparations were used as antigens without the chromatographic procedure, they were all immunogenic. Now we could realize that it was due to the antibody producing capacity of the single strand form present in the preparations. As regards the instability of methylated DNA to heat, other research workers (Lawley and Brookes 1963 ; Pochon and Michelson 1967) have reported that Me-DNA is labile to heat, and that the liberation of 7-methylguanine is caused by the extremely labile glycosyl linkage in 7methyldeoxyguanosine. Under the conditions described in the present paper, only 7-methylguanine was detected as a modified base of Me-DNA. Then, we followed the antigenic change of Me-DNA heated at varied conditions and we could demonstrate the quantitative relationship between the liberation rate of 7-methylguanine from deoxyribose phosphate backbone of Me-DNA and the deterioration of the antigenic reactivities (Fig. 8). Consequently, it may be said that a single strand structure as well as 7-methylguanine residues have the essential role in forming the epitopes of Me-DNA. The applicability of the antibodies in biological system has not been examined.

\section{References}

1) Bernardi, G. (1971) Chromatography of nucleic acids on hydroxyapatite columns. In: Methods in Enzymology, edited by L. Grossman \& K. Moldave, Academic Press, New York, Vol. 21, Part D, pp. 95-139.

2) Beverly, W.L. \& Erlanger, F.B. (1978) Antibodies to poly d (A-T) and their reactions with oligonucleotides and nucleic acids. Immunochemistry, 15, 663-671.

3) Forsen, N.R., Alspaugh, M. \& Barnett, E.V. (1970) Precipitating antibodies to DNA induced by heat-denatured DNA-albumin conjugates in the rabbit. Immunology, 19, 669-676.

4) Guigues, M. \& Leng, M. (1976) Antibodies to poly (I). poly (C) : Purification and interaction with polynucleotides. Europ. J. Biochem., 69, 615-625.

5) Igarashi, J. \& Okuhara, E. (1976) Antigenicity of methylated deoxyribonucleic acid. Tohoku J. exp. Med., 120, 25-30.

6) Kitagawa, Y. \& Okuhara, E. (1980) Demonstration of the production of specific antibodies to poly (I) $\cdot$ poly (C) in rabbits. J. Biochem., 88, 1607-1613.

7) Kitagawa, Y., Matsumoto, T. \& Okuhara, E. (1977) Immunogenicity of rice dwarf virus-ribonucleic acid. Tohoku J. exp. Med., 122, 337-343.

8) Lafer, E.M., Möller, A., Nordheim, A., Stollar, B.D. \& Rich, A. (1981) Antibodies specific for left-handed Z-DNA. Proc. nat. Acad. Sci. USA, 78, 3546-3550.

9) Lawley, P.D. \& Brookes, P. (1963) Further studies on the alkylation of nucleic acids and their constituent nucleotides. Biochem. J., 89, 127-138.

10) Mandell, J.P. \& Hershey, A.D. (1960) A fractionating column for analysis of nucleic acids. Analyt. Biochem., 1, 66-77.

11) Marmur, J. (1961) A procedure for the isolation of deoxyribonucleic acid from micro-organisms. J. molec. Biol., 3, 208-218.

12) Matsumoto, T. \& Okuhara, E. (1974) Separation and characterization of immunoglobulin classes of anti-salmon deoxyribonucleic acid antibodies in rabbits. Tohoku 
J. exp. Med., 113, 245-255.

13) Okuhara, E. (1970) Preparation of mammalian deoxyribonucleic acid by SDS-phenol treatment. Analyt. Biochem., 37, 175-178.

14) Plescia, J.O. (1964) Production of antibodies to denatured deoxyribonucleic acid. Proc. nat. Acad. Sci. USA, 52, 279-285.

15) Pochon, F. \& Michelson, A.M. (1967) Polynucleotides IX. Methylation of nucleic acids, homopolynucleotides and complexes. Biochim. biophys. Acta, 149, 99-106.

16) Schwartz, E.F. \& Stollar, B.D. (1969) Antibodies to polyadenylate-polyuridinate copolymers as reagents for double strand RNA and DNA-RNA hybrid complexes. Biochem. biophys. Res. Commun., 35, 115-120.

17) Stollar, B.D. (1970) Double-helical polynucleotides: Immunochemical recognition of differing conformations. Science, 169, 609-611.

18) Stollar, B.D. (1973) Nucleic acid antigens. In: The Antigens, edited by M. Sela, Academic Press, New York, Vol. 1, pp. 1-85. 